\title{
Demystifying the Program of Demythologizing: Rudolf Bultmann's Theological Hermeneutics
}

\author{
David W. Congdon
}

IVP Academic

I

More than seventy years after Rudolf Bultmann delivered his famous lecture on the topic of "New Testament and Mythology" in 1941 - initially on April 21 in Frankfurt am Main and again on June 4 in Alpirsbach - the program of demythologizing is still widely misunderstood, perhaps more so now than ever. Erroneous views have gradually accreted around Bultmann's original hermeneutic, so that now what is generally criticized under the name of "demythologizing" bears little resemblance to the intended program.

To take one recent example, we read in Kevin Vanhoozer's Remythologizing Theology that demythologizing is "a strategy for translating biblical statements about God into existential statements about human beings." ${ }^{1}$ Vanhoozer repeats the outdated criticism of John Macquarrie, Fritz Buri, and Schubert Ogden that Bultmann sets an arbitrary limit on demythologizing by refusing to " "anthropologize' all the way down," as if anthropologizing were his goal in the first place. ${ }^{2}$ As a result, we are told that "Bultmann is critical of the mythos or system of projection employed by the biblical authors for speaking of God's acts but uncritical of his own." ${ }^{3}$ It follows, naturally, that "Bultmann fails to see that his own articulation of God's acts simply substitutes one system of projection for another," and thus "fails to recognize the forms of biblical discourse as themselves indispensable means for

${ }^{1}$ Kevin J. Vanhoozer, Remythologizing Theology: Divine Action, Passion, and Authorship (Cambridge, UK: Cambridge University Press, 2010) 15.

${ }^{2}$ Ibid., 16.

${ }^{3}$ Ibid., 17.

HTR 110:1 (2017) 1-23 
articulating and thinking the reality of God. Demythologizing consequently denarrativizes and generally de-forms the biblical rendering of God and his acts."4 Bultmann allegedly "dedramatizes the theodrama," "sides with the philosophers over the poets," and ends up with "a theos without logos," a "faith without understanding." ${ }^{5}$ While rhetorically clever, these claims end up begging the question by presupposing certain accounts of scripture and theology that Bultmann wishes to examine critically. ${ }^{6}$ Moreover, Vanhoozer only cites two of Bultmann's texts - the programmatic essay of 1941 and the 1951 lectures, Jesus Christ and Mythologybut all of the decisive support for his interpretation is found in secondary sources, and particularly in highly critical interpreters who have a vested interest in opposing Bultmann's position.?

4 Ibid.

${ }^{5}$ Ibid., 17. The poet Robert Duncan delivered a more belligerent version of this critique in his 1968 manifesto, "The Truth and Life of Myth": "The voice [Bultmann] impersonates here [in a previously quoted passage from the 1941 programmatic lecture] is a voice that has again and again, sneering or pitying or condescending, reproved the poet for his pathetic fallacies, his phantasmagoria, his personifications, ecstatic realizations, pretensions... . [Bultmann] reproves the imagination itself" ("The Truth and Life of Myth: An Essay in Essential Autobiography [1968]," in Collected Essays and Other Prose [ed. James Maynard; Berkeley: University of California Press, 2014] 139-94, at 158). I hope to show that, when Bultmann speaks of myth, he does not have something generic, like "imagination," in mind.

${ }^{6}$ For example, one cannot criticize Bultmann for failing to recognize that "the forms of biblical discourse" are themselves necessary and indispensable, as if this should have been obvious to him, since that is the very issue that Bultmann disputes. The first to argue this position against Bultmann was Helmut Thielicke in 1942. Thielicke correctly saw that defending the necessity of myth requires defending a certain account of the relation between nature and grace, where grace assumes and perfects a natural "point of connection" that includes ancient mythology. His rejection of Bultmann thus required the adoption of natural theology ("Die Frage der Entmythologisierung des Neuen Testaments [1942]," in Kerygma und Mythos, Band I. Ein theologisches Gespräch [ed. Hans-Werner Bartsch; Hamburg: Reich, 1948] 177-210, esp. 195-208). Asserting the necessity of mythical discourse without affirming natural theology results in an incoherent position, as Bultmann already saw in 1961. In his final clarification of demythologizing, he observes that "it is often said that religion as well as Christian faith cannot do without mythological talk." But either this means that the images and symbols of myth are themselves revelation - hence natural theology — or they are a contextualization of revelation that can be interpreted within a different cultural-linguistic form. If the meaning of mythological talk can only be expressed in the same mythological talk, then "its meaning must again be interpreted - and so on in infinitum" ("Zum Problem der Entmythologisierung [1961]," in Glauben und Verstehen. Gesammelte Aufsätze [4 vols.; Tübingen: Mohr, 1933-1965] 4:128-37, at 134-35). Hereafter Glauben und Verstehen cited as GuV. All German translations in this article are my own. While there are English translations for many of the pieces cited, they are often unreliable, and trying to cite both versions quickly becomes cumbersome.

${ }^{7}$ I especially have Buri and Ogden in mind here, both of whom are clear about their rejection of Bultmann's adherence to the exclusive normativity of God's revelation in Christ. They thus approach Bultmann's demythologizing hermeneutic assuming this program supports their own project and then charge him with inconsistency when it does not. One finds a more accurate interpretation in the work of Eberhard Jüngel, who rightly sees demythologizing as grounded in and in service to God's revelation in Christ (Gottes Sein ist im Werden. Verantwortliche Rede vom Sein Gottes bei 
Vanhoozer is only one among many critics who judge Bultmann's hermeneutical program to be on the side of an alien philosophy over and against Christian theology. A consistent line of critique is that demythologizing makes modern science the norm of what is authentically Christian. Heike Peckruhn, a postcolonial feminist theologian, claims that Bultmann called on theologians "to revise their Christian message in light of scientific methods," thereby bringing Christianity "into the modern, progressive era." ${ }^{8}$ On her reading of Bultmann, the kerygma has to be "extracted from these mythological components" through the use of universal scientific methods.9 "Privileging the scientific mind-set and dismissing other worldviews as primitive," she says, "Bultmann attempts to make faith relevant to the modern mind." ${ }^{10}$ Much more problematically, Peckruhn claims that Bultmann's very method is based on a "Heideggerian racist framework," and that "Heidegger's racialized philosophy guides Bultmann in his work." 11 Other critics do not make such morally freighted judgments, but their statements are no less condemnatory of Bultmann. Udo Schnelle, in his Theology of the New Testament, claims that "R. Bultmann's 'demythologizing' proceeds not only from a historical but also from a material [sachlichen] superiority of modern natural-scientific thinking." 12 David Bentley Hart similarly asserts that Bultmann presupposes a purely immanent account of the world and then "defines univocally as 'myth' whatever is not recognizably immanent within this narrowly imagined chain of effects."13 According to such a reading, myth names whatever Bultmann deems false and antiquated. As C. Stephen Evans puts it, Bultmann's proposal "assumes that myths are false explanations of phenomena in the natural world." 14

Karl Barth. Eine Paraphrase [4th ed.; Tübingen: Mohr, 1986] 23-24, 33-34; idem, "Die Wahrheit des Mythos und die Notwendigkeit der Entmythologisierung [1990]," in Indikative der Gnade Imperative der Freiheit. Theologische Erörterungen 4 [Tübingen: Mohr, 2000] 40-57).

${ }^{8}$ Heike Peckruhn, "Rudolf Bultmann," in Beyond the Pale: Reading Theology from the Margins (ed. Miguel A. De La Torre and Stacey M. Floyd-Thomas; Louisville, KY: WJK, 2011) 191-200, at 191.

${ }^{9}$ Ibid., 193.

${ }^{10}$ Ibid., 196.

${ }^{11}$ Ibid., 195. Peckruhn is here drawing on Shawn Kelley's recent work, which argues that Bultmann's interpretations "are racialized, irrespective of Bultmann's intentions," on the grounds that the "fundamental structure" of his thought is determined by "Heideggerian categories" (Shawn Kelley, Racializing Jesus: Race, Ideology, and the Formation of Modern Biblical Scholarship [London: Routledge, 2002] 141, 159 [italics in original]). This is not the place to address Kelley's critique of Bultmann in any detail, which rests on the illegitimate conflation of Bultmann's theological judgments and his philosophical conceptuality, as well as a basic misunderstanding of each aspect. The point here is that Kelley at least indicates a tension in Bultmann, insofar as he was a vocal opponent of Nazi antisemitism and actively supported the Jews in Germany. Peckruhn's summary of Kelley lacks this nuance entirely and so portrays Bultmann even more negatively and simplistically.

${ }^{12}$ Udo Schnelle, Theologie des Neuen Testaments (Stuttgart: Vandenhoeck \& Ruprecht, 2007) 162 n. 64.

${ }^{13}$ David Bentley Hart, The Beauty of the Infinite: The Aesthetics of Christian Truth (Grand Rapids: Eerdmans, 2003) 22.

${ }^{14}$ C. Stephen Evans, The Historical Christ and the Jesus of Faith: The Incarnational Narrative as History (Oxford: Oxford University Press, 1996) 64. 
There are, to be sure, other interpreters who present Bultmann in a more favorable light, ${ }^{15}$ but the overall verdict regarding demythologizing is still overwhelmingly negative. Indeed, the idea that demythologizing is a hermeneutic that subjects the New Testament message to the dictates of modern science is almost certainly the majority opinion. In some circles it has become a truism. And yet, as Eberhard Jüngel says regarding similar claims, such descriptions of Bultmann's theology are "largely grounded in a grotesque misunderstanding of his statements," a misunderstanding which betrays "a fatal inability to read and an unwillingness to think." 16 We are thus led to echo Jüngel's question: "Why then are the most questionable interpretations of Bultmann preferred to an interpretation of Bultmann 'in bonam partem'?"17

More is at stake, however, than just reading Bultmann in a charitable way. If, as I will argue, demythologizing is actually a way of criticizing aspects of modernity - not only its scientific reductionism but also and especially its tendency toward totalizing political worldviews - then the debate over his hermeneutical program has wider implications for the church in contemporary society. The radical critique of demythologizing that worries many of Bultmann's readers with respect to scripture and tradition is the very means by which he articulates the kerygma's freedom from every form of cultural captivity, including modernity itself. By misrepresenting his views, Bultmann's critics risk repeating the very social and cultural objectifications of revelation that he was seeking to resist. The question to pose to his critics is whether, in criticizing Bultmann's translation of the kerygma for a modern context, they have not presupposed a direct identification of the kerygma with some other context.

This essay will therefore interrogate the view that demythologizing is a species of "liberal theology," 18 by which I mean the notion that demythologizing is determined and normed by the concern to make the gospel acceptable to modern western society. Put another way, this critique views demythologizing as a hermeneutic that plays logos off against mythos, which submits the New Testament message to the criteria of modern science. To expose this misunderstanding, I will:

1) demonstrate the basis for this hermeneutic in the revelatory truth of myth that stands over against science;

\footnotetext{
${ }^{15}$ For example, Tim Labron is correct when he says that "Bultmann is not trying to tie the kerygma to science or any one perspective to make it more acceptable. . . . Demythologizing does not take the modern view as the benchmark to fit into" (Bultmann Unlocked [London: T \& T Clark, 2011] 36).

${ }^{16}$ Eberhard Jüngel, "Glauben und Verstehen: Zum Theologiebegriff Rudolf Bultmanns," in Wertlose Wahrheit. Zur Identität und Relevanz des christlichen Glaubens - Theologische Erörterungen III (Munich: Kaiser, 1990) 16-77, at 68.

17 Jüngel, Gottes Sein ist im Werden, 41 n. 116.

${ }^{18}$ I use the word "liberal" here to refer to the tradition of nineteenth-century German theology descended from Friedrich Schleiermacher and synthesized by Albrecht Ritschl, represented in Bultmann's time by Adolf von Harnack and Ernst Troeltsch. Liberal theology is not simply the reinterpretation of Christian doctrine under the conditions of modernity; it is instead the systematic and strategic coordination of Christian faith and modern European culture.
} 
2) examine Bultmann's program of demythologizing as a response to the tendency of myth to slide into scientific objectification (Objektivierung); and

3) argue that demythologizing pursues a mode of analogical God-talk determined by revelation.

Toward the end I will respond briefly to the charges of anthropocentrism and gnosticism in Bultmann and will show instead how demythologizing is intrinsically oriented to the sociopolitical situation of the believer. Though unable to address all of the many criticisms, this initial effort to clarify the program of demythologizing will disclose the genuinely theological nature of Bultmann's hermeneutic as a method of hearing and responding appropriately to the event of God's self-revelation in Christ.

\section{II}

The task of demystifying the program of demythologizing must begin by dispelling the view that Bultmann's hermeneutic promotes the superiority of science over myth by associating science with truth and myth with falsehood. According to this position, Bultmann's program belongs to the long tradition of myth-criticism - a tradition that originated with Heraclitus and Plato, was embraced within certain streams of ancient Christianity (see, e.g., 1 Tim 1.4, 4.7; Titus 1.14; 2 Pet 1.16, as well as later patristic theologians), ${ }^{19}$ and reached its apotheosis with the likes of Hegel, ${ }^{20}$ David Friedrich Strauss, and Adolf von Harnack. ${ }^{21}$ Bultmann

${ }^{19}$ See Jüngel, “Die Wahrheit des Mythos und die Notwendigkeit der Entmythologisierung,” 45-46.

${ }^{20}$ It does not help Bultmann's reputation that Thomas Lewis draws a connection between demythologizing and Hegel's conceptualization of religion, given Hegel's reputation ("Religion and Demythologization in Hegel's Phenomenology of Spirit," in Hegel's Phenomenology of Spirit: A Critical Guide [ed. Dean Moyar and Michael Quante; New York: Cambridge University Press, 2008] 192-209). Cyril O'Regan made this connection back in 1994, when he described Hegel's representation of Christian religion as a "demythologization" that is actually "Christianity-friendly in a way the other modern forms are not. Indeed, his demythologization . . . is necessary to subvert the hostile demythologization that Hegel thought was well under way in his own day" (The Heterodox Hegel [Albany, NY: State University of New York Press, 1994] 334). Hegel's demythologizing is Christianity-friendly, according to O'Regan, because it preserves the content of Christian faith. As Lewis points out, however, “one person's friend may be another's foe," and indeed scholars like William Desmond see Hegel as a threat to Christianity on the grounds that he loses divine transcendence. "The fact that Hegel sees the elevation of religious representation into thought as a 'friendly' process does not mean that everyone will. The transformation does abandon aspects of religion that some view as a matter of content rather than form" (Thomas A. Lewis, Religion, Modernity, and Politics in Hegel [Oxford: Oxford University Press, 2011] 164; cf. William Desmond, Hegel's God: A Counterfeit Double? [Aldershot, UK: Ashgate, 2003] 6). Lewis's comments regarding Hegel apply mutatis mutandis to Bultmann. Nevertheless, one cannot accuse Bultmann of lacking divine transcendence. In fact, that is the very doctrine that funds his entire hermeneutical program, as Jüngel has pointed out (Jüngel, "Die Wahrheit des Mythos und die Notwendigkeit der Entmythologisierung," 50).

${ }^{21}$ Erich Przywara speaks for many when he says that "Harnack and, more recently, Bultmann sought to eradicate the offensive 'mysterium' (Harnack) and the offensive 'mythos' (Bultmann), in order to attain a 'pure' (de-mysticized [ent-mysterisiertes] and demythologized) Christianity" (Analogia Entis. Metaphysik. Ur-Struktur und All-Rhythmus [Schriften 3; Einsiedeln: Johannes, 1962] 352). 
unintentionally contributes to the misunderstanding in a few ways. For instance, he claims that his concept of myth is taken from history-of-religions research, which is at best only a half-truth. ${ }^{22}$ More famously, he says in the programmatic essay that "one cannot use an electric light and the radio, or make use of modern medicine and clinical resources in cases of illness, and at the same time believe in the spirit- and wonder-world of the New Testament." 23 This line is deliberately provocative and easily misleading when read out of context and apart from a wider understanding of Bultmann's project. Finally, of course, the results of Bultmann's hermeneutical program share some superficial similarities to liberal Enlightenment programs of the nineteenth and early twentieth centuries.

To understand what is really driving demythologizing, we need to look more closely at his concept of myth. Readers of Bultmann are often confused by the way he describes myth as being at times similar to science and at other times the opposite of science. We will defend a twofold thesis: 1) myth is dissimilar to science in terms of its existential truth, but 2) myth is similar to science in terms of its objectifying untruth. What these two claims reveal is that far from promoting some progression from myth to science, Bultmann actually elevates myth over science as genuinely in touch with the truth of human existence. The problem with myth is, in fact, that it is too similar to science, not that it is dissimilar or inferior, as the Enlightenment criticism of myth would claim. As we will see, demythologizing derives from the existential truth of myth and criticizes the objectifying untruth that characterizes both myth and science.

Bultmann was prompted to clarify his understanding of the myth-science relationship with the 1940 publication of Wilhelm Nestle's From Mythos to Logos, which presents the western tradition as a linear progression from mythical thinking to scientific reason. ${ }^{24}$ In addition to writing a highly critical review of Nestle's book, ${ }^{25}$ Bultmann responded by composing a brief essay on the topic, "On the Concept of "Myth," which he never saw published. ${ }^{26}$ The central concern of

${ }^{22}$ Rudolf Bultmann, Neues Testament und Mythologie. Das Problem der Entmythologisierung der neutestamentlichen Verkündigung (ed. Eberhard Jüngel; Munich: Kaiser, 1985) 22-23 n. 20; idem, "Zum Problem der Entmythologisierung," in Kerygma und Mythos, Band II. Diskussion und Stimmen zum Problem der Entmythologisierung (ed. Hans-Werner Bartsch; Hamburg-Volksdorf: Reich, 1952) 179-208, at 180.

${ }^{23}$ Bultmann, Neues Testament und Mythologie, 16.

${ }^{24}$ See Wilhelm Nestle, Vom Mythos zum Logos. Die Selbstentfaltung des griechischen Denkens von Homer bis auf die Sophistik und Sokrates (Stuttgart: Kröner, 1940).

${ }^{25}$ See Rudolf Bultmann, Theologie als Kritik. Ausgewählte Rezensionen und Forschungsberichte (ed. Matthias Dreher and Klaus W. Müller; Tübingen: Mohr, 2002) 394-97.

${ }^{26}$ Rudolf Bultmann, "Über den Begriff 'Mythos' [ca. 1942-1952]," in Bultmann-Althaus Briefwechsel 1929-1966 (ed. Matthias Dreher and Gotthard Jasper; Tübingen: Mohr, 2012) 89-96. While the essay was unpublished, there is no indication that it represents views that Bultmann later rejected. Many of Bultmann's most important writings remained unpublished during his lifetime, including his 1941 lecture on "Theology as Science" and his lectures on theological encyclopedia from 1926-1936, which he explicitly wanted to see in print; both were finally published in 1984 (“Theologie als Wissenschaft," ZThK 81 [1984] 447-69; idem, Theologische Enzyklopädie [ed. 
this piece is to clarify the concept of myth in distinction from science. Bultmann acknowledges a certain shared starting-point, in that both myth and science are positively "concerned with the grasping of my existence." That is to say, both arise out of the "question of existence" and are thus attempts to understand the human person's being in the world. ${ }^{27}$ In this limited respect, there is a positive commonality between them. But Bultmann quickly observes that myth and science grasp existence in fundamentally different ways - and it is myth that captures the truth of existence, in contrast to science.

The difference between them is that "mythical thinking is guided by the question of existence not only in its origin but also in its execution," whereas scientific thinking "certainly has its origin also in the question of existence, but it is not guided by this question in its execution (in its method)." ${ }^{28}$ Myth is constantly oriented by the question of existence, while science leaves that question behind. This indicates that the two ways of speaking about our being in the world provide two qualitatively different answers to the question of existence. Put another way, each is guided by a different "existential decision," a different understanding of what constitutes genuine existence. The decision animating science "is alien to myth," being "the view that human persons gain their authenticity not in their encounters and decisions but in the fact that they understand themselves as links in the entire cosmos." ${ }^{29}$ Science therefore does not thematize the question of existence but instead thematizes "the question of the unity and structure of the cosmos." In doing so, scientific thinking treats the question of existence by in effect "reduc[ing] this question to the question of human beings in general, so that in order to understand myself, I do not have to inquire after my existence but must understand myself as an instance of the general." ${ }^{30}$ According to the scientific perspective, each particular human person within history is simply a species within the genus. Science diverts attention away from the historical moment to an ahistorical totality. In this way,

Eberhard Jüngel and Klaus W. Müller; Tübingen: Mohr, 1984]). Moreover, many of the ideas in the essay are stated similarly elsewhere, both in his review of Nestle's book and in his later 1952 essay, "Zum Problem der Entmythologisierung." For these reasons, German scholars have been referring to the essay for several years now. See, for example, Matthias Dreher, Rudolf Bultmann als Kritiker in seinen Rezensionen und Forschungsberichten. Kommentierende Auswertung (Münster: Lit, 2005) 338-39; Werner Zager, “Zwischen Kerygma und Mythos. Karl Jaspers' und Rudolf Bultmanns Beitrag zur Debatte über die Entmythologisierung der Bibel," in Mensch und Mythos. Im Gespräch mit Rudolf Bultmann (ed. Werner Zager; Neukirchen-Vluyn: Neukirchener, 2010) 29-58, at 41-42. See also Matthias Dreher, "Exegetisch-theologischer Kommentar," in Bultmann-Althaus Briefwechsel 1929-1966 (ed. Matthias Dreher and Gotthard Jasper; Tübingen: Mohr, 2012) 117-19.

${ }^{27}$ Bultmann, "Über den Begriff 'Mythos,"” 94.

${ }^{28}$ Ibid., 95. In all of his essays on myth, Bultmann uses the terms myth, mythology, and mythical/ mythological thinking almost interchangeably. Generally, though, the terms myth and mythical thinking are used more positively, while mythology and mythological thinking are used more pejoratively.

29 Ibid.

${ }^{30}$ Ibid. 
science loses the particular historicity of the person who speaks of God by collapsing that person's history into the general being of the cosmos. Science therefore rules out any genuine talk of God, given that God does not encounter people in general but only in a particular time and place.

Bultmann traces this approach to the question of existence back to the fact that "it

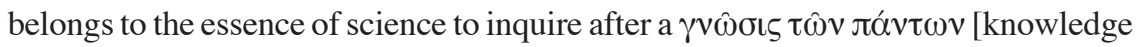
of all things]." Scientific thinking attempts "to include all the phenomena of the cosmos in general in its field." ${ }^{31}$ It is this pursuit of a comprehensive knowledge of all things that leads science to bypass the historicity of the particular entity in favor of its place within the whole. Bultmann elsewhere refers to this comprehensive knowledge of all things as a Weltanschauung or worldview. In a lecture given on 11 June 1925, on "The Christian Meaning of Faith, Love, Hope," Bultmann describes a worldview as "a theory about the world as a totality-about its formation, its progression, and its meaning." 32 A worldview "proceeds in general propositions" by "disregarding my concrete existence in the here and now." For this reason, "the attempt at a worldview is ultimately based on an interpretation of human existence that sees its essence in the general and timeless, which I can perceive by abstraction from myself, and thus by an observation of the human person, which considers the person in each case as an instance of the human species. ${ }^{.33}$ What Bultmann calls scientific thinking in the 1940s is what he identified in the 1920s as worldviewthinking. Either way, it is an epistemological method that pursues a totalizing and ahistorical knowledge of the world and human existence. It approaches the world in the posture of a "nonparticipating curiosity," ${ }^{34}$ or what he later calls "disinterested seeing. ${ }^{35}$ Scientific thinking thus maintains an objectifying distance from the object of its inquiry that precludes the possibility of an existential encounter.

Whereas "scientific inquiry understands the human person as a unity that is contrasted to the cosmos, and recognizes a person's existence and movement to be rational," and thus capable of being fit within a comprehensive worldview, "myth does not know this distance from the cosmos that belongs to the scientific vision, but rather it considers itself in direct encounter with the cosmos." ${ }^{\prime 36}$ Contrary to "distance-establishing scientific thinking," myth pursues a participatory or existential understanding of the "phenomena and events" of life; unlike science,

${ }^{31}$ Ibid., 94. In contrast to myth, Bultmann writes, "it is precisely science that is concerned with

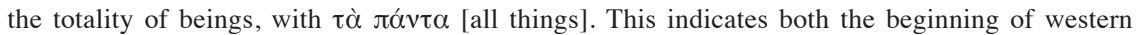

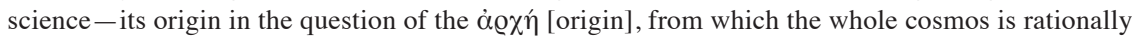
understandable as a structured unity - and its fulfillment in antiquity in Aristotle" (ibid., 93).

${ }^{32}$ Rudolf Bultmann, "Der christliche Sinn von Glaube, Liebe, Hoffnung. Skizze des am 11. Juni 1925 vor der 50. Versammlung evangelischer Religionslehrer an den höheren Lehranstalten der Rheinprovinz gehaltenen Vortrages," ZEvRU 36 (1925) 170.

${ }^{33}$ Ibid. All emphasis in original unless otherwise noted.

${ }^{34}$ Bultmann, "Über den Begriff 'Mythos,"” 95.

${ }^{35}$ Rudolf Bultmann, "Wissenschaft und Existenz [1955]," in GuV 3:107-21, at 108.

${ }^{36}$ Bultmann, "Über den Begriff 'Mythos,", 89. 
it refuses "to reduce [the new, the interesting, and the strange] to the known and familiar." ${ }^{37}$ In his 1942 review of Nestle's book, Bultmann rejects the modern disparagement of myth by stating that "myth is not primarily concerned with a (primitive) world-explanation, in which, as in science, the world is objectified, but rather myth is an understanding of reality that is opposed to rational thinking." 38 Jüngel clarifies Bultmann's position when he says that myth "lacks the subjectobject-divide" and is thereby able to move a person into "a new existential location" through its narration of the world. Myth achieves a "practical knowledge," which Jüngel calls the "truth of myth." ${ }^{39}$ While science or worldview-thinking, according to Bultmann, operates with a disinterested and objectifying observation of the world, myth empowers the subject to existentially participate in the object, that is, to exist in a direct encounter with the other. Myth in general has this capacity, but it is true in a unique and decisive way for New Testament mythology.

Instead of reducing the particular to the general, myth in the New Testament seeks to understand the concrete, personal encounter with God in history. Biblical myth does not seek to establish an abstract worldview, in which God and human beings are mere objects. Myth seeks to account for my existence and not simply existence as such. ${ }^{40}$ In this way the myth that appears in the New Testament texts becomes a vehicle for revelation, that is to say, it becomes the bearer of truth.$^{41} \mathrm{In}$ the programmatic essay of 1941 Bultmann calls this mythical truth "the Christian understanding of being," according to which God is "the creator of the world" and thus "the judge before whom a person is responsible." 42 Within this understanding of the creator-creature relationship, one recognizes that true (or authentic) existence is not something available and at our disposal but is rather a gift that we must receive. To live responsibly is to live 'out of faith in God's 'grace,' that is, out of trust that precisely the invisible, unfamiliar, and inaccessible encounters people as love, brings them their future." And this "grace of God is sin-forgiving grace, that

37 Ibid.

${ }^{38}$ Bultmann, Theologie als Kritik, 396.

${ }^{39}$ Jüngel, "Die Wahrheit des Mythos und die Notwendigkeit der Entmythologisierung," 49-50.

${ }^{40}$ In his emphasis on the situation of the individual believer, Bultmann stands in the tradition of the Protestant reformers, particularly Luther and Calvin, who rejected the Roman Catholic doctrine of fides implicita and insisted that sin is something for which individuals are guilty first and foremost, and thus justification is primarily a relation between God and the individual believer.

${ }^{41}$ Secular myth-theorists understand this aspect of Bultmann better than his theological critics. Robert Segal correctly observes that "as a religious existentialist . . . Bultmann takes myth to be preserving the reality of God, simply of a nonphysical god [sic]. . . Bultmann retains an ancient myth with its God" (Robert A. Segal, "Does Myth Have a Future?" in Myth and Method [ed. Laurie L. Patton and Wendy Doniger; Charlottesville, VA: University Press of Virginia, 1996] 82-106, at 93).

${ }^{42}$ Bultmann, Neues Testament und Mythologie, 32. 
is, it liberates people from their past, which holds them captive." ${ }^{43}$ In other words, the basic truth of New Testament mythology is that God justifies the ungodly. Or as Bultmann says in 1953, justification by faith alone is the "content of revelation," and thus it is the content of biblical mythology. ${ }^{44}$

Bultmann's hermeneutical project is to understand the revelatory content that comes to expression in the New Testament. In his response to Karl Jaspers, he explains that this project is grounded normatively in the absoluteness of divine revelation, which declares: "I am the Lord your God. You shall have no other gods before me!" 45 If revelation confronts each person with God's sovereign claim, then demythologizing has the hermeneutical task of helping people to hear this divine claim in its full contemporary significance, so that the response to God's word is an appropriate one. Contrary to widespread misunderstanding, "the goal of demythologizing is not . . . to make the faith acceptable to modern people, but rather to make it clear what the Christian faith is, and thereby to place a person before the question of decision, a decision that is provoked precisely by the offence, the $\sigma x \alpha v^{\prime} \delta \alpha \lambda o v$, of the question of faith - an offence that is not made especially obvious to modern people but to people in general (of which modern people are only

${ }^{43}$ Ibid., 34.

${ }^{44}$ Rudolf Bultmann, "Antwort an Karl Jaspers [1953]," in Kerygma und Mythos, Band III. Das Gespräch mit der Philosophie (ed. Hans-Werner Bartsch; Hamburg-Volksdorf: H. Reich, 1954) 49-59, at 57. We cannot emphasize this soteriological point strongly enough. The most widespread criticism of Bultmann is that he reduces theology to anthropology and confines Christian truth to an inner, spiritual realm apart from the world. And it is further supposed by many that Bultmann adopts this view from Kant and Heidegger, as if it were grounded in some extratheological philosophy. Amos Wilder thus asks: "Do we move as he [Bultmann] does from the pictorial and representational character of the myth to its supposed meaning for the heart alone? Or should we not recognize that the symbol, for all its imaginative and ancient character, yet tells us something Christian not only about ourselves but also about the visible world of time and space and about the work of God in a real world process? Our choice here rests in part upon our view of mythological language and cultural symbol, and our view as to what kind of truth they possess. Existentialism sees this truth as truth primarily about man. . . . Demythologizing at this point appears to rest upon a sceptical legacy from the thought of Kant" (Early Christian Rhetoric: The Language of the Gospel [Cambridge, MA: Harvard University Press, 1971] 125-26). Wilder operates under the misunderstanding that Bultmann's concept of myth is basically equivalent to other literary devices, such as symbol and image, but we can set that aside for now. Wilder's more serious misunderstanding concerns his view that the truth of myth in Bultmann is anthropological. While it is true that Bultmann denies that revelation gives us general knowledge about the world and history, he grounds this view on a strictly theological claim regarding the nature of our justification in Christ. The truth of myth is soteriological, and only for this reason is it anthropological. But because it is soteriological, Bultmann denies that we can responsibly interpret it as giving general knowledge about the empirical world. That would be to turn myth into science and thereby to abandon the truth of myth altogether.

${ }^{45}$ Bultmann, "Antwort an Karl Jaspers," 56. Bultmann, like Barth, makes the first commandment the axiom of theology (Karl Barth, "Das erste Gebot als theologisches Axiom [1933]," in Vorträge und kleinere Arbeiten 1930-1933 [ed. Michael Beintker, Michael Hüttenhoff, and Peter Zocher; Gesamtausgabe 3; Zürich: TVZ, 2013] 209-41). This is ironic, since Barth's 1933 lecture was directed in large part against Bultmann. 
a species)." ${ }^{46}$ Bultmann's hermeneutical program serves the truth of revelation by removing the "other gods" - the cultural, philosophical, and religious notions - that obstruct and obfuscate God's self-disclosure. ${ }^{47}$ There is nothing intrinsically modern about this program; it is a hermeneutic that is, in principle, relevant to every situation wherein one speaks of God. Demythologizing is essentially the task of ensuring that the revelatory truth of myth - defined as a personal and saving encounter with the transcendent God-is genuinely heard and understood in a particular context.

\section{III}

So far we have demonstrated that Bultmann differentiates between myth and science on the grounds that myth is the bearer of an existential truth. In the New Testament, this is the truth of our dependence upon and responsibility to God, a truth concretely expressed in the doctrine of justification by grace and faith alone. It is this soteriological truth that funds Bultmann's program of demythologizing. The question now is why such a program is necessary. To answer that, we need to examine the way in which myth, according to Bultmann, is also similar to science and thus at odds with God's revelation. As Bultmann states in 1952, myth is "an objectifying thinking like that of science." 48 This thesis will serve as our guide to the problem of myth that demythologizing aims to address.

We begin by returning to Bultmann's unpublished essay on the concept of myth. Despite differentiating the existential truth of myth from science, Bultmann recognizes that "existential questions . . . and inquisitive, primitive scientific questions may blend together; genuine myth is able to slide into primitive science." ${ }^{49}$ Myth is constantly in danger of abandoning its truthful character. Instead of making sense of the antinomies and complexities of worldly existence, myth can becomeor be interpreted as - an etiological explanation of the world and our existence in it. Myth is primarily a "practical knowledge" that existentially relocates the knower, but myth can also be a "theoretical knowledge" that seeks to provide a "mythical world-explanation [Welterklärung]." ${ }^{50}$ When Bultmann says in his demythologizing essays that he uses the concept of myth in the sense meant within the history of religions, it is this theoretical, world-explaining version of myth that he has in

${ }^{46}$ Bultmann, "Antwort an Karl Jaspers," 50.

${ }^{47}$ Bultmann can thus declare in 1952 that the program of demythologizing is simply "the consistent application of [the doctrine of justification through faith alone] to the field of knowledge" ("Zum Problem der Entmythologisierung," 207).

${ }^{48}$ Ibid., 183.

${ }^{49}$ Bultmann, "Über den Begriff 'Mythos,"” 90.

${ }^{50}$ Jüngel, "Die Wahrheit des Mythos und die Notwendigkeit der Entmythologisierung," 49-50. 
mind - that is, myth as a Weltanschauung.$^{51}$ His essays on demythologizing appeal to the definition of myth provided in the history of religions, since "religious studies largely overlooks the originally existentialist [existentiale] meaning of myth and understands myth in general (because it is a mode of etiology) as a primitive form of scientific thinking." 52 While he is critical of this reductionistic understanding of myth, which lacks appreciation for myth's truth, it nevertheless captures what he means to criticize in his hermeneutical program.

Myth warrants hermeneutical critique when it becomes a worldview, that is, when it becomes a theoretical explanation of the world. This can happen in two senses, in accordance with the two elements in Bultmann's composite definition of myth. We have already noted that he defines myth as an "objectifying thinking" like science, but we also have to account for the difference between mythical and scientific thinking. Bultmann does so by introducing the term Weltbild or "worldpicture," which we must differentiate from "worldview." ${ }^{33}$ According to the famous opening line of his programmatic lecture of 1941: "The world-picture of the New Testament is a mythical world-picture. ${ }^{, 54} \mathrm{He}$ contrasts the mythical world-picture, which is impossible to repristinate, with the "natural-scientific world-picture," which is the cultural milieu of modern western humanity. ${ }^{55}$ Myth and science are two versions of objectifying thinking within different world-pictures: "Just as the mythical world-picture is a 'perforated' world-picture, so too is mythical thinking;

51 "Myth slips from its original meaning and starts to become a primitive science" whenever it

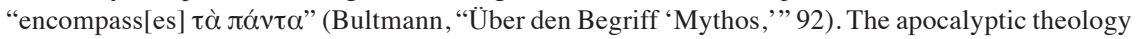
of Second Temple Judaism represents, for Bultmann, a classic example of existential myth sliding into primitive science: "One can see . . . this in the prophetic theology of history. The mythical view of history is of course first formed in Jewish apocalyptic, in which mythical thinking has already slipped into scientific thinking; for apocalyptic thinking, like that of Gnosticism, is a mixture of mythological and scientific thinking" (ibid., 93).

52 Ibid., 90.

53 The distinction can be traced back to Wilhelm Dilthey and comes down to the difference between 1) our given (i.e., generally prereflective) cultural preunderstanding regarding the world in which we live and 2) a specific, determinate understanding of our place within this world. Bultmann first makes this distinction in his 1925 essay, "What Does It Mean to Speak of God?" There he says that a world-picture is "conceptualized without regard for our own existence." It is an understanding of the world in which "we consider ourselves rather as an object among other objects and so positioned in the context of this world-picture that has been constructed without regard for the question of our own existence." It naturally follows that a worldview takes existence into consideration: "it is customary to call the completion of such a world-picture through the insertion of humanity a worldview" ("Welchen Sinn hat es, von Gott zu reden? [1925]," in GuV 1:26-37, at 31). He clarifies his definition of Weltbild many years later in a 1953 conversation: "I am of the opinion that all people, whether they live in a mythical age or an enlightened age, have a Weltbild, live in a Weltbild, by which I naturally do not mean that this Weltbild must be a closed and systematic Weltbild. The fact that people can go about their daily activities and communicate with their fellow human beings all presupposes that a definite Weltbild is taken for granted" (Die christliche Hoffnung und das Problem der Entmythologisierung [Stuttgart: Evangelisches Verlagswerk, 1954] 46-47).

${ }^{54}$ Bultmann, Neues Testament und Mythologie, 12.

55 Ibid., 17. 
just as the scientific world-picture presupposes the closedness of the world, so scientific thinking is a continuous thinking." ${ }_{56}$ We can therefore define myth as an objectifying thinking within an ancient and foreign world-picture.

Understanding Bultmann can be difficult, because he places the emphasis in the 1941 essay on the world-pictures that divide myth and science, while in 1951 and beyond he places the emphasis on the objectifying thinking that unites myth and science. We can only interpret demythologizing accurately if we see both emphases as equally necessary elements in his definition of myth. In correspondence to the dual nature of myth as 1) an objectifying thinking that 2) belongs to a foreign worldpicture, mythical talk of God presents a twofold problem for theology. On the one hand, myth objectifies revelation, and so treats God like an object of science. On the other hand, and at the same time, myth binds revelation to a foreign world-picture, and so confuses God with the assumptions of a cultural context. Demythologizing addresses both problems, though in the space remaining we will focus only on the issue of objectification. ${ }^{57}$

In Bultmann's judgment, mythical God-talk is intrinsically in danger of becoming a worldview by virtue of speaking about a transcendent God. This problem is not unique to myth, of course, since all God-talk runs the risk of falsely representing a God who cannot be captured by language. ${ }^{58}$ But myth is especially prone to this risk. Insofar as myth, in its narrative world-explanation of existentially meaningful experiences, naively represents divine action as one immanent causal force among others, it functions as a form of scientific thinking, as an objectification of what

\footnotetext{
${ }^{56}$ Bultmann, "Über den Begriff ‘Mythos,"” 92. For Bultmann, objectifying thinking (objektivierendes Denken) represents the scientific untruth that demands critique, while historical understanding (geschichtliches Verstehen) represents the existential truth of the kerygma. For more on this distinction, see Bernhard Dieckmann, "Welt” und "Entweltlichung” in der Theologie Rudolf Bultmanns. Zum Zusammenhang von Welt- und Heilsverständnis (Munich: Schöningh, 1977) 120-27.

${ }^{57}$ The two problems go hand-in-hand. Insofar as God is made an object of our rational control, God is also conflated with our cultural norms. To oppose the objectification of God is thus to oppose the way religion often seeks to give divine sanction for certain cultural assumptions and practices. Demythologizing is a way of recognizing the kerygma's capacity to be a critical force within the present context.

${ }^{58}$ Bultmann is well aware of this danger. At the end of his 1925 lecture on what it means to speak of God, he concludes: "Even this speaking is a speaking about God, and as such, if there is a God, it is sin, and if there is no God, it is meaningless. Whether it is meaningful and whether it is justified cannot be decided by us" ("Welchen Sinn hat es, von Gott zu reden?" in GuV 1:37).
} 
cannot be objectified. Science necessarily objectifies the world, while myth, in its attempt to interpret the truth of human existence before God, unwittingly ends up objectifying God as part of the worldly nexus, contrary to its "real intention." 59 The rationale for demythologizing thus has its basis "in myth itself." 60

As early as 1927, Bultmann states that myth "speaks of God as the beyond of human beings, even if it speaks humanly of God." ${ }^{61}$ Here we have an inchoate articulation of both the existential truth ("God as the beyond") and the objectifying untruth ("speaks humanly of God") ${ }^{62}$ Years later, in his 1951 lectures given at Yale and Vanderbilt, he finds the truth of myth in the conviction "that the world and life have their ground and their limits in a power that is beyond all that we can calculate and control." But mythology speaks about this power "as a worldly power" and gives "transcendent reality an immanent, worldly objectivity. Myth objectifies the transcendent as immanent." 63 The next year, in his most important essay on demythologizing, Bultmann criticizes myth for speaking about divine power "as analogous [analog] to immanent powers and as superior to these powers only in force and unpredictability." ${ }^{64}$ Clarifying what he means by analogy, he adds: "myth makes the gods (or God) into vastly superior human beings, and it does this even when it speaks of God's omnipotence and omniscience, because

\footnotetext{
${ }^{59}$ One should not make too much of Bultmann's use of the language of intention. He has little interest in the debates over "authorial intention." In this context, he simply means it is self-evident that the text intends to portray God as a truly transcendent and saving power. Objectifying God is clearly not the goal of the text. It only appears objectifying to those of us who now read it many centuries later.

${ }^{60}$ Bultmann, Neues Testament und Mythologie, 23. When Hart criticizes Bultmann for confining theology within an immanent causal nexus, he is describing what Bultmann himself criticizes as science and thus what he also criticizes as myth, insofar as the latter takes the corrupt form of a worldview. It is precisely to preserve the genuine transcendence of God that he engages in demythologizing.

${ }^{61}$ Rudolf Bultmann, "Das Johannesevangelium in der neuesten Forschung [1927]," in Theologie als Kritik, 204-15, at 214. Bultmann actually broaches the idea two years earlier in his 1925 study of Mandaean and Manichaean sources in the study of the Fourth Gospel. There he speaks at length about myth as the material out of which John is formed. Near the end of the article he says that "the author [of John] is interested only in the that of the revelation, not in the what," which means that revelation cannot be described "through speculative sentences or through mental states, because both drag revelation down into the human sphere. It cannot be said of God how God is, but only that God is. The divine is not in any way given and describable" ("Die Bedeutung der neuerschlossenen mandäischen und manichäischen Quellen für das Verständnis des Johannesevangeliums [1925]," in idem, Exegetica. Aufsätze zur Erforschung des Neuen Testaments [ed. Erich Dinkler; Tübingen: Mohr, 1967] 55-104, at 103).

${ }^{62}$ The language of objectification appears in relation to myth beginning with his programmatic lecture of 1941. In the unpublished essay on myth written shortly thereafter, he describes myth as "a mode of thinking and speaking that objectifies the unworldly [Unweltliche] as something worldly [Welthafte]" (Bultmann, "Über den Begriff 'Mythos,"” 89).

${ }^{63}$ Rudolf Bultmann, Jesus Christus und die Mythologie. Das Neue Testament im Licht der Bibelkritik (Hamburg: Furche, 1964) 17.

${ }^{64}$ Bultmann, "Zum Problem der Entmythologisierung," 183.
} 
it does not differentiate these qualitatively, but only quantitatively, from human capability and knowledge." ${ }^{65}$ Bultmann's critique of mythology is thus primarily theological. Mythical God-talk is an objectifying thinking in the sense that it violates the creator-creature distinction. ${ }^{66}$

It is important to notice the direction of this analogy. For Bultmann, "mythological thinking [in the New Testament] objectifies divine action and projects it onto the plane of worldly occurrences." ${ }^{67} \mathrm{He}$ does not say, by contrast, that New Testament mythology begins with the human person and projects some creaturely capacity upon the idea of God, as in the ancient Dionysian method of the via eminentiae. He explicitly denies this. In a 1952 pamphlet on Bultmann, Karl Barth challenged the concept of myth operative in demythologizing. He questioned whether the term was "so formal" that it covered both historical myths (e.g., Indian and Babylonian mythology) and modern myths (e.g., "Myth of the Twentieth Century, Marxist myth, myth of the Christian west, etc."). ${ }^{68}$ Bultmann responded to this charge by differentiating between two kinds of myth: "The 'Myth of the Twentieth Century" is a perverted myth. If genuine myth is the immanentizing of the transcendent, then the myth of the twentieth century is the transcendentizing (absolutizing) of the immanent." ${ }^{69}$ Alfred Rosenberg's Nazi "myth of the twentieth century" is "perverted" because it moves from the immanent to the transcendent and thereby divinizes German culture; the result is an ideology that lacks any revelatory truth. In the 1952 clarification of his hermeneutical project, he thus states in a footnote that "one should not orient oneself to the 'myth of the twentieth century' in order to define the concept of "myth." "70 Insofar as ancient biblical mythology is "genuine myth," it begins with a theological truth rooted in revelation; it speaks about a transcendent God who justifies the ungodly, even if it finally speaks about this God in an inappropriate way.

${ }^{65}$ Ibid., 184. Cf. Bultmann, "Zum Problem der Entmythologisierung (1961)," in GuV 4:134.

${ }^{66}$ It is therefore ironic that Vanhoozer charges Bultmann with replacing statements about God with statements about human beings, since Bultmann is trying to oppose precisely that problem.

${ }^{67}$ Bultmann, "Zum Problem der Entmythologisierung," 196.

${ }^{68}$ Karl Barth, Rudolf Bultmann. Ein Versuch, ihn zu verstehen (Zollikon-Zürich: Evangelischer Verlag, 1952) 31-32. The reference to Alfred Rosenberg's 1930 work of Nazi propaganda, Der Mythus des 20. Jahrhunderts, was hardly accidental. Bultmann had already publicly rejected this work in 1936, and the Confessing Church, a group of which was the audience for his demythologizing lecture, was actively involved in opposing Rosenberg (Harald Iber, Christlicher Glaube oder rassischer Mythus. Die Auseinandersetzung der Bekennenden Kirche mit Alfred Rosenbergs "Der Mythus des 20. Jahrhunderts" [Frankfurt am Main: Lang, 1987]). On Bultmann's lecture as a rejection of Rosenberg and Nazi propaganda, see Wichmann von Meding, "Rudolf Bultmanns Widerstand gegen die Mythologisierung der christlichen Verkündigung," ThZ 53 (1997) 195-215.

${ }^{69}$ Rudolf Bultmann to Karl Barth, 11-15 November 1952, in Karl Barth and Rudolf Bultmann, Briefwechsel 1911-1966 (ed. Bernd Jaspert; 2nd ed.; Gesamtausgabe 5; Zürich: TVZ, 1994) 181.

${ }^{70}$ Bultmann, "Zum Problem der Entmythologisierung," 180 n. 2. 
Bultmann's reference to analogy should not be taken as a blanket rejection of analogous God-talk. Later in his 1952 essay he argues that responsible talk of God's action "is not a pictorial, symbolic mode of speaking, but instead an analogical speech." "At issue here is the kind of analogy, which then determines the appropriate creaturely analogue for divine action. As we noted above, Bultmann rejects God-talk that posits an analogy between divine action and immanent forces - namely, natural causes that modern science now understands, such as bacteria or plate tectonics. He criticizes myth insofar as it "represents the origin of the world in God according to

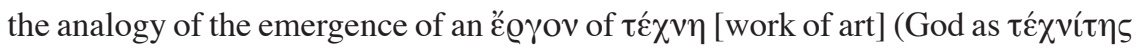
[artisan]) or according to the analogy of a plant's development."72 These forms of analogical God-talk attempt to convey an existentially significant truth-for instance, our utter dependence upon God for life - but they do so by projecting this truth into objectifying pictures and symbols, such as human society, artistic creation, or plant life. The result is that they shoehorn God into a predetermined conceptual framework. ${ }^{73}$ Myth, in this sense, functions as a Weltanschauung, as a mode of scientific thinking.

\section{IV}

The aim of Bultmann's hermeneutics is to differentiate between myth as science and myth as the vehicle of revelation. Negatively, demythologizing criticizes the tendency of mythical speech to slide into a mode of scientific speech that constructs a worldview and turns God into an object within the world. Positively, demythologizing is the interpretation and repetition of myth's truth within a new time and place. If myth is an objectifying thinking insofar as it represents God through an inappropriate mode of analogical speech, then demythologizing pursues a nonobjectifying God-talk that represents God through an appropriate mode of analogical speech. ${ }^{74}$

${ }^{71}$ Ibid., 196.

${ }^{72}$ Bultmann, "Über den Begriff 'Mythos,'” 89.

${ }^{73}$ Kevin Hector calls this shoehorning of God "metaphysics," which he characterizes in terms of essentialism and correspondentism: "Metaphysics fits God . . . into an essentialist-correspondentist framework, such that God, too, is conceived as an object which corresponds to one's preconceptions. That is to say, if God is thought to correspond to one's ideas of God, then God will be cut down to size like any other object. . . Metaphysical theism thus appears guilty of a particular sort of idolatry, namely, that of attempting to speak of God by speaking of human persons in a loud voice." He further points out that "a theology that does without metaphysics . . . is roughly equivalent to one that does without natural theology (in Barth's sense) and objectification (in Bultmann's)" (Theology without Metaphysics: God, Language, and the Spirit of Recognition [Cambridge, UK: Cambridge University Press, 2011] 13, 3 n. 2).

${ }^{74}$ The first to really explore this idea was Schubert Ogden in his 1961 study, Christ without Myth. My argument for an understanding of demythologizing as analogy differs from Ogden in that I 1) differentiate between two views of analogy in Bultmann (negative and positive) and 2) deny Ogden's constructive project in process theology, which leads him to criticize Bultmann for not expanding his view of analogy to allow for a philosophical knowledge of God (Christ without Myth: A Study Based on the Theology of Rudolf Bultmann [New York: Harper, 1961] 90-93, 147, 
The analogical speech of demythologizing differs from that of objectifying mythology by letting revelation determine the appropriate creaturely analogue. Revelation, as we examined earlier, is understood here as the christologicallygrounded truth of our absolute dependence upon God's grace for our existence, concretely expressed in the doctrine of justification through faith alone. Given that revelation is a personal word from and encounter with Christ that elicits our response, it follows that responsible analogical God-talk must itself be personal language that draws on the experience of encounter with others. A demythologizing hermeneutic therefore "grasps God's action as corresponding [eine Entsprechung] to the actions between human persons," or "represents the community between God and the human person as corresponding to the community between one person and another." 75 Understanding the mystery of God, Bultmann is fond of saying, is like understanding love and friendship. Science cannot grasp the truth of God in the same way that "science can never discover a friend, fidelity, or love." " In a 1930 article he puts forward the "analogy" between knowing God and knowing a friend..$^{77}$ The transition between unbelief and belief is like the transition from having knowledge about friendship to finding a friend. One does not necessarily gain any new information about friendship, nor does the transition consist in something objectively visible. Just as the love of God cannot be objectified as a worldly datum, so too the love of another person is not "a given fact open to the observation of a third person," " but always remains a personal encounter: "The love of my friend, my wife, my children . . . cannot be observed with objective methods, but only encountered in personal experience and response." ${ }^{.79}$ But the change in reality that comes through this personal encounter is nevertheless a radical one: "I know my friend, and I know myself anew... . Through the event of friendship the events of my life become new." ${ }^{80}$ Demythologizing serves the truth of myth over against the objectifying observation of science by interpreting the acts of God in terms of the personal encounter of faith, which grants a person a wholly new self-understanding.

151). Eberhard Jüngel, while critical of Ogden's overly positive claims about demythologizing and analogy, nevertheless gestures in the direction of the present argument. In a footnote in his 1965 work, God's Being Is in Becoming, Jüngel connects what demythologizing rejects with what Karl Barth calls the "analogy of being" (analogia entis) and connects what demythologizing affirms with Barth's notion of the "analogy of faith" (analogia fidei). For Jüngel, Bultmann's program is the analogia fidei in a hermeneutical mode (Gottes Sein ist im Werden, 23-24 n. 34).

${ }^{75}$ Bultmann, Jesus Christus und die Mythologie, 80; cf.idem, "Zum Problem der Entmythologisierung," 196.

${ }^{76}$ Bultmann, Theologische Enzyklopädie, 59. Cf. idem, Jesus Christus und die Mythologie, 48; idem, "Zum Problem der Entmythologisierung," 190.

${ }^{77}$ Rudolf Bultmann, "Die Geschichtlichkeit des Daseins und der Glaube. Antwort an Gerhardt Kuhlmann [1930]," in Neues Testament und christliche Existenz. Theologische Aufsätze (ed. Andreas Lindemann; Tübingen: Mohr, 2002) 59-83, at 70.

${ }^{78}$ Rudolf Bultmann, "Wahrheit und Gewißheit [1929]," in Theologische Enzyklopädie, 201.

${ }^{79}$ Bultmann, Jesus Christus und die Mythologie, 84.

${ }^{80}$ Bultmann, "Die Geschichtlichkeit des Daseins und der Glaube," 70. 
Analogical God-talk funded by demythologizing does not simply assume that interpersonal relations provide a point of connection with divine action. Instead, in light of the existential event of revelation, it discovers - and continually rediscovers - that such relations help articulate the works of God. There is the danger, of course, that one will turn talk of relations between persons into a new worldview, a new "scientific" objectification of God. This is why truly analogical God-talk must always be existential God-talk: "Because God is not an objectively discernable phenomenon of the world, we are only able to speak of God's action if we speak at the same time of our existence as affected by God's action. One may call this mode of speaking of God's action 'analogical." "81 Existence is here defined theologically (not philosophically) as being-affected-by-God, and this affectedness "has its origin strictly in God," such that in the presence of this divine action we are "merely those who are passive, those who receive." ${ }^{22}$ Genuinely analogical Godtalk therefore has to account for the significant disanalogy between one's personal encounter with God and one's encounter with a friend or neighbor, namely, that our encounter with God is not a generic relation but a uniquely salvific one, wherein we receive the eschatological gift of grace. Analogical talk of God is dependent upon the reality of one's justification through faith alone.$^{83}$ Epistemology, in other words, is inseparable from soteriology.

If God's justifying work in Christ is the analogans in relation to which our creaturely existence and God-talk is the analogatum, then it follows that we must speak in a very particular way in order to speak appropriately of God. Since justification does not occur as an empirical datum that we can observe and control-in which case it would be law rather than gospel-we cannot speak of God's action as operating at the level of the empirical world. This leads Bultmann in his later writings to develop the concept of paradoxical identity, which he connects directly to analogy. After stating that talk of God's action "is not a pictorial, symbolic mode of speaking, but instead an analogical speech," he draws a contrast between mythological thinking, which represents divine action "as something happening between worldly occurrences," and a nonmythological thinking, which represents divine action "as something taking place in them." 84 But whereas pantheism establishes a direct identity between such occurrences and divine action, "faith affirms the paradoxical identity," meaning that "God's action is hidden from all eyes other than the eyes of faith." ${ }^{\circ 5}$ In other words, both mythology

${ }^{81}$ Bultmann, "Zum Problem der Entmythologisierung (1961)," in GuV 4:135.

${ }^{82}$ Ibid. On the passivity of faith in Bultmann's theology, see Jüngel, "Glauben und Verstehen," 58-61.

${ }^{83}$ The same holds true in Barth's doctrine of analogy (Keith L. Johnson, Karl Barth and the Analogia Entis [London: T \& T Clark, 2010] 11, 26, 29, 97, 108, 120, 149).

${ }^{84}$ Bultmann, "Zum Problem der Entmythologisierung," 196.

${ }^{85}$ Ibid., 196-97. 
and pantheism - another term for liberal theology, in Bultmann's writings ${ }^{86}$ - are scientific objectifications of God: each speaks about God as an objective piece of the world, as something immanent and available. Whether done unintentionally (myth) or intentionally (liberalism), objectifying thinking denies the transcendence of God revealed in the message of Christ's justifying grace. As if to cement his point that the problem with myth - in both its ancient and modern iterations - is its scientific character, Bultmann follows his discussion of paradoxical identity by stating that "Christian faith is not a 'worldview.' . . Such faith is not a knowledge possessed once and for all, not a 'worldview,' but it can only be an event in each situation." 87

To sum up, demythologizing speaks analogically of the God who justifies the ungodly by criticizing generalized, objectifying speech about God and pursuing God-talk that is existential and paradoxical. In doing so, it brings to expression the ever new event of revelation that captures human language and interrupts a person's existence.

\section{V}

At this point it may be worth addressing some potential criticisms. Bultmann's account of the kerygma - the truth of myth — is commonly charged with being 1) anthropocentric and 2) gnostic. The former would call into question Bultmann's claim to be engaging in analogical talk of God, while the latter would vitiate his claim to be talking of the God revealed in Christ.

Richard Hays is the most recent scholar to raise the issue of anthropocentrism in Bultmann. In his contribution to a volume assessing Bultmann's Theology of the New Testament, Hays claims that Bultmann interprets Paul "from the side of the human experience," and thus stands in "a well-established trajectory in German Protestant theology that dates back at least to Friedrich Schleiermacher. ... Indeed, I would suggest that . . . [Bultmann] risks reducing Paul's message to an anthropocentric meditation on human religious psychology, its limits, and its possibilities." Paul's proclamation of God's reconciling work "is converted through Bultmann's anthropocentric emphasis into a message about our human Daseinsverständnis." ${ }^{88}$ Like Vanhoozer, Hays disputes whether Bultmann is properly engaged in theology at all. ${ }^{89}$

${ }^{86}$ In one of his earliest essays, Bultmann calls liberal theology a "pantheism of history" (Geschichtspantheismus), in distinction from the more common "pantheism of nature" ("Die liberale Theologie und die jüngste theologische Bewegung [1924]," in GuV 1:1-25, at 5).

${ }^{87}$ Bultmann, "Zum Problem der Entmythologisierung," 197.

${ }^{88}$ Richard B. Hays, "Humanity Prior to the Revelation of Faith," in Beyond Bultmann: Reckoning a New Testament Theology (ed. Bruce W. Longenecker and Mikeal C. Parsons; Waco, TX: Baylor University Press, 2014) 61-78, at 63-64.

${ }^{89}$ It is unclear whether Hays believes this is true for Bultmann in general, for his Theology of the New Testament, or only for the chapter to which he was assigned. The section on humanity prior to faith is certainly focused on anthropological concepts in Paul, but the following section 
The truth of myth, as I have described it here, is indeed existential in character. As a message of justification by grace, it must be a truth directed toward the human person. To understand why this is not a reduction to "human religious psychology," Hays would have done well to consider Bultmann's early writings, particularly his 1925 lecture on what it means to speak meaningfully of God. In that document, Bultmann differentiates between two forms of God-talk: speaking "about God" (über Gott) and speaking "of God" (von Gott). ${ }^{90}$ He associates the former with worldview-thinking. It is a form of God-talk that does not take into consideration God's revealing and justifying action towards human beings. Given our analysis above, we can describe speaking "about God" as scientific God-talk. By contrast, speaking "of God" is a form of God-talk determined by "the claim of God on us," a claim that precludes all attempts at objectivity and neutrality, and demands instead our personal involvement and commitment. For this reason, "if one wishes to speak of God, one must evidently speak of oneself." ${ }^{91}$ But lest we conclude, like Hays, that this means we can talk simply of human experience, Bultmann is quick to point out:

No speaking of ourselves can ever be a speaking of God, because it only speaks of the human person. ... Every speaking of experience and inner life would be a speaking of humanity. . . . Indeed, even my own experiences . . . would dissolve in my hands. . . . If we therefore wish to speak of God, we evidently cannot begin by speaking of our experiences and our inner life, for they lose their existential character as soon as we objectify them. ${ }^{92}$

For Bultmann, God-talk is existential without being anthropocentric, because our life becomes genuinely existential only when it is theocentric. Responsible analogical talk of God thus only occurs at the site where the human person encounters God..$^{33}$ As Bultmann states in an earlier lecture, "the object of theology is God, and theology speaks of God in that it speaks of human beings as they stand before God." 94 Any attempt to speak outside of this position before God results in scientific, objectifying God-talk..$^{95}$

on humanity under faith contains sustained discussion of divine action. It is nigh impossible to reconcile Hays's comments with the rest of Bultmann's writings.

${ }^{90}$ Bultmann, "Welchen Sinn hat es, von Gott zu reden?" in GuV 1:26.

91 Ibid., 28.

92 Ibid., 28-29.

${ }^{93}$ Bultmann recognizes that the human person stands before God not as an isolated individual but as a social being. The love of God, he says, "determines me in my being-with-others" ("Das christliche Gebot der Nächstenliebe [1930]," in GuV, 1:242). But he refuses to abandon the witness of the New Testament to the necessity of personal faith. Each person is responsible before God. In that sense, the kerygmatic truth of myth is individual, though not for that reason individualistic. Bultmann is fond of saying that "a faith which concentrates on itself is just as little faith as a love which concentrates on itself is love" (Theologische Enzyklopädie, 157).

${ }^{94}$ Bultmann, "Die liberale Theologie und die jüngste theologische Bewegung," in GuV 1:25.

${ }^{95}$ For a more complete defense of Bultmann see Benjamin Myers, "Faith as Self-Understanding: Towards a Post-Barthian Appreciation of Rudolf Bultmann," International Journal of Systematic Theology 10 (2008) 21-35. 
At the same time, others charge Bultmann with being too theocentric, that is to say, too focused on the God who is "wholly other." His criticism of scientific objectification is thus seen as a gnostic rejection of the objective world as such. David Bentley Hart, for instance, calls Bultmann's theology "a gnostic etiolation of the gospel," which "necessarily terminates in a gnosticism that extracts from the mire of created contingency a purely spiritual, formless, inward, and unutterable wisdom, disabused of all illusion." ${ }^{\prime 96}$ It would be too much in this space to respond fully to the charge of gnosticism, and the above argument for analogical God-talk already addresses the assertion that Bultmann promotes an "unutterable wisdom." The concern here is to clarify his concept of paradox. The fact that divine action is hidden and paradoxical, and thus not objectifiable or empirical, does not mean it is any less worldly, or that it occurs in some inward recess of the soul. Bultmann concludes his programmatic lecture with the words of John 1:14, "the word became flesh," for this very reason. ${ }^{97}$ Christ is the divine word within the flesh. Faith that corresponds to this paradoxical reality is "[eschatological] existence within the world," while the community of faith "realize[s] its [eschatological] being as a worldly community." 98

Bultmann promotes the nonobjectifiable and paradoxical truth of myth over against every scientific worldview not in order to remove God and faith from the world, but rather precisely to clarify the responsibility of the Christian within a world enslaved to objectifying political powers. ${ }^{99}$ The first appearance of Weltanschauung in his lectures on theology occurs in a section added in 1933, where he speaks of "the National Socialist "worldview." 100 He criticizes "the so-called worldview of the National [Socialist] movement" for being "an ideology" that has slipped into "romanticism and materialistic biology." 101 The theological problem of science and worldviews is a fundamentally sociopolitical problem. This is the context within which we have to read his programmatic lecture in 1941.

${ }^{96}$ Hart, The Beauty of the Infinite, 22-23.

${ }^{97}$ Bultmann, Neues Testament und Mythologie, 64.

${ }^{98}$ Rudolf Bultmann, "Das Befremdliche des christlichen Glaubens [1958]," in GuV 3:207; idem, Das Evangelium des Johannes (Göttingen: Vandenhoeck \& Ruprecht, 1941) 384. In both quotes the word replaced by "eschatological" is "entweltlichte," best translated as "deworldlized." Bultmann's concept of Entweltlichung is too complex to clarify here. The word "eschatological" captures his meaning, and he often uses the two concepts synonymously.

${ }^{99}$ Many of the critics cited at the start of this article would affirm Bultmann's criticism of political objectification though not his criticism of mythical objectification, but they cannot have it both ways. By tying the kerygma to the cultural-linguistic forms of biblical discourse, one implies that certain objectifications or worldviews are permissible, even necessary. The question then is: on what grounds and to what extent is scripture or tradition protected from criticism, and how then does one mount a coherent response when that very act of protection produces ideological distortions of the faith?

${ }^{100}$ Bultmann, Theologische Enzyklopädie, 8.

${ }^{101}$ Ibid., 64. 


\section{VI}

It is easy to lose sight of the historical situation in which Bultmann delivered his lecture on demythologizing. He delivered it in the spring of 1941 before the Gesellschaft für evangelische Theologie (Society for Protestant Theology), a group of theologians of the Confessing Church that started gathering in February 1940 for the purpose of responding to the threat posed by National Socialism. ${ }^{102}$ If we read the essay with this audience in mind, we begin to see that the problem he exposes is less about the presence of myth in the Bible and more about how our interpretation of this mythical material is connected to the way we interpret and respond to our contemporary cultural and political situation.

In October 1940, he delivered another lecture before the same group on "The Question of Natural Revelation." ${ }^{103}$ Like many of Bultmann's subversive wartime lectures, this piece appears to be concerned with a purely academic theological problem, in this case the debate over the relation between revelation and nature made prominent by the dispute between Barth and Brunner. Bultmann, however, quickly dismisses the idea of natural revelation as a nonsensical notion and turns instead to his real concern: the relation between revelation and history. Here we find the real motive for the piece, namely, the claim by German Christians that the history of the German people is a criterion for divine revelation. Bultmann responds by rejecting every identification of the divine will with a phenomenon of history. ${ }^{104}$ All God-talk on the basis of nature and history, he argues, ends up talking not of God but of a mere illusion, since the revelation of God is exclusively located in Jesus Christ.

Bultmann's decision to publish the 1940 and 1941 lectures together in the volume, Offenbarung und Heilsgeschehen, indicates something very significant about both lectures. As Konrad Hammann points out in discussing the lecture on natural revelation, "with this highly political statement in 1940-41, Bultmann provided an example of a theological dispute with current myths." 105 Seen in this light, it becomes clear that, in his demythologizing program, Bultmann is interrogating the ancient antecedents to modern ideology. By addressing the objectifying character of ancient mythology, demythologizing simultaneously addresses the myth of National Socialism, which, as we already noted, he specifically criticizes as a worldview.

${ }^{102}$ According to Konrad Hamman, "The 'Society for Protestant Theology' pursued its work with the goal of closely combining academic theology and church proclamation in order to be able to fend off the ideological [weltanschaulichen] attacks of the Nazi state against Christianity" (Rudolf Bultmann. Eine Biographie [Tübingen: Mohr, 2009] 308).

${ }^{103}$ Rudolf Bultmann, "Die Frage der natürlichen Offenbarung [1941]," in GuV 2:79-104.

${ }^{104}$ Ibid., 92-93.

${ }^{105}$ Hammann, Rudolf Bultmann, 309; italics mine. Cf. Bernd Jaspert, "Sachkritik und Widerstand. Das Beispiel Rudolf Bultmanns," ThLZ 115 (1990) 161-82. 
Both are examples of a false scientific thinking - though the latter is an especially pernicious version. As Jacob Taubes observes, "the program of demythologizing ... is a product of the protest against the rampant 'Myth of the Twentieth Century,' and in the early 1940s . . . it did not lack a political edge."106

In conclusion, as Jüngel recognized long ago, demythologizing is a program in service of revelation. Demythologizing has nothing to do with "generalized truths about individual existence" 107 that could, in theory, be derived from philosophy or religious experience. Bultmann's hermeneutical program is instead built on the premise that God has spoken and continues to speak to historical human beings, but that in order for this divine speech to be heard as the word of God-and in order for one's response to God's word to be genuine and appropriate God-talk - it is necessary to differentiate God from the world, the kerygma from worldviews, theology from science. Demythologizing is a hermeneutic of the word of God-a consistently and radically theological hermeneutic. ${ }^{108}$

${ }^{106}$ Jacob Taubes, "Zur Konjunktur des Polytheismus," in Mythos und Moderne. Begriff und Bild einer Rekonstruktion (ed. Karl Heinz Bohrer; Frankfurt am Main: Suhrkamp, 1983) 469.

${ }^{107}$ According to Ben Dunson, "Demythologization is thus built on the premise that generalized truths about individual existence can be gleaned from the thoroughly mythological texts of the New Testament" (Individual and Community in Paul's Letter to the Romans [Tübingen: Mohr, 2012] 30).

${ }^{108} \mathrm{I}$ am grateful to the two anonymous reviewers for their astute comments. 